\title{
Incorporating river morphological changes to flood risk assessment: uncertainties, methodology and application
}

\author{
C. Neuhold, P. Stanzel, and H. P. Nachtnebel \\ Institute of Water Management, Hydrology and Hydraulic Engineering - IWHW, University of Natural Resources and \\ Applied Life Sciences - BOKU, Vienna, Austria
}

Received: 24 October 2008 - Revised: 15 May 2009 - Accepted: 15 May 2009 - Published: 27 May 2009

\begin{abstract}
Risk zonation maps are mostly derived from design floods which propagate through the study area. The respective delineation of inundated flood plains is a fundamental input for the flood risk assessment of exposed objects. It is implicitly assumed that the river morphology will not vary, even though it is obvious that the river bed elevation can quickly and drastically change during flood events. The objectives of this study were to integrate the river bed dynamics into the flood risk assessment procedure and to quantify associated uncertainties. The proposed concept was applied to the River Ill in the Western Austrian Alps. In total, 138 flood and associated sediment transport scenarios were considered, simulated and illustrated for the main river stem. The calculated morphological changes of the river bed at the moment of peak flow provided a basis to estimate the variability of possible water surface levels and inundation lines which should be incorporated into flood hazard assessment. In the context of vulnerability assessment an advanced methodological approach to assess flood risk based on damage probability functions is described.
\end{abstract}

\section{Introduction and objectives}

Alluvial river beds are subjected to severe morphological changes during flood events which have significant implications for the water level (Nachtnebel and Debene, 2004). This effect has to be considered in the delineation of flood endangered riparian zones. Risk zonation maps are mostly derived from single design floods which represent a hazard based on a specified return period. The respective delineation

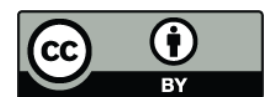

Correspondence to: C. Neuhold (clemens.neuhold@boku.ac.at) of inundated areas and the estimation of flow depths and flow velocities are fundamental inputs for flood risk estimation of exposed objects. For this purpose in most cases 2-D hydrodynamic unsteady models are applied (BMFLUW, 2006a). It is implicitly assumed that the morphology will not change; neither during flood events nor by long term erosion or deposition. However, it is obvious that the river bed elevation can change quickly and drastically. Quantitatively and qualitatively observed morphological developments during and after flood events indicate, to some extent, tremendous changes in river bed elevation due to sediment transport, log jam, rock jam, etc. The occurrence of such processes clearly implies the necessity of incorporating calculated or estimated morphological changes to the flood risk assessment procedure. Therefore, the influence of sediment transport on the respective water surface elevation which is in most cases neglected during flood events and related uncertainties are investigated.

It is obvious that uncertainty increases as an additional process is considered. The identification of partially known impacts on the water surface elevation and accordingly the possible inundation depth as well as delineation could, however, lead to an increase of awareness and an adaptation of flood risk management strategies. The study focuses on uncertainties related to hazard assessment covering aspects of hydrology, hydraulics and sediment transport. Furthermore, the study aims to enhance methodologies of vulnerability assessment and therefore, damage estimation by providing a direct link of probability distribution functions of inundation depths with the respective damage functions of flood-prone utilisations (damage-probability relationship).

The concept was tested on the Ill catchment which has suffered three major floods during the recent past $(1999,2000$ and 2005). The considered catchment area is characterized by torrential tributaries, hydraulic structures, hydropower

Published by Copernicus Publications on behalf of the European Geosciences Union. 
plants and partially complex morphological characteristics. Therefore, it was crucial to apply a model with no restrictions and limitations regarding internal and external boundary conditions. Apart from these demands, a calculation in different fractions of sediment was required.

The paper gives an overview of sources of uncertainty to outline complexity and lack of approaches as well as methodologies to quantify risk (Sect. 1). Following this introduction the study area is characterized. In Sect. 2 the applied methodology is described in detail. Section 3 presents the results of the conducted study. Conclusions are given in Sect. 4.

\subsection{Uncertainties}

The assessment of flood damage imports uncertainties from the climatic, hydrologic and hydraulic domain, adds some of its own uncertainties and exports the resulting composite uncertainties to the decision domain (Messner et al., 2007). Contemplating the above mentioned uncertainties, a distinction has to be made between reducible (epistemic) and irreducible (aleatoric) uncertainty (Merz, 2006; Apel et al., 2008; Hall and Solomatine, 2008). Aleatoric uncertainty results from the variability and unpredictability of the considered natural processes. Epistemic uncertainty is a product of imperfect knowledge (lack of research, measurements and models) of the examined system. Murphy (1998) subsumes three origins of uncertainties: the incompleteness of considered scenarios and assumptions as well as simplifications inherent to models and model parameters as described in the following sections.

\subsubsection{Scenario uncertainty}

Risk analysis is typically characterized by sets of a few damage scenarios. Obviously, these scenarios cannot cover all the possible future events and their definition is based, to a larger extent, on subjective expert judgements. There are always scenarios that will not be considered because of:

- Low probability of recurrence and therefore, a negligible ("not significant") influence on the overall expected losses

- Lack of data and methodologies to calculate or describe rare events

- Deficit of experience and analytical skills of the person responsible

Incompleteness and representation of a collection of damage scenarios are fundamental problems in the frame of risk assessment (Kaplan and Garrick, 1981). Incompleteness leads to uncertain results and accordingly, the underestimation of risk. Uncertainty can be reduced by experience and sound methodological approaches. It is essential that the chosen scenarios are representative for the overall considered system. The set of scenarios should also include the worst case scenario even though it might have little impact on the result due to its recurrence interval.

\subsubsection{Model uncertainty}

The overall uncertainty of many surveys is dominated by model uncertainty (Kuikka and Varis, 1997). Merz (2006) stated that model uncertainty emerges from:

- Model assumptions and composition

- Model sufficiency (completeness)

- Model domain and resolution

Precipitation-runoff models, hydrodynamic models and sediment transport models rest upon simplified model assumptions. To some extent, there are alternative or even contradicting assumptions or theories of model development. Models are approximations of natural processes - their composition demands decisions upon which processes should be described and which accuracy and abstraction is necessary or possible. Moreover, the spatial and temporal discretisation of models influences uncertainty and should be determined as a compromise of computing time and approximation degree. To summarise, a maxim can be stated: a model should be composed as simply as possible but as complex as necessary (Popper, 1982).

\subsubsection{Natural variability and parameter uncertainty}

Parameter uncertainty comprises uncertainty related to model parameters and variables. These are mainly parameters and variables representing measurable attributes of the considered system e.g. intensity of precipitation, infiltration capacity of soil, failure rate of system components or costs due to blocking roads. Uncertainty of parameters and variables results from:

- Variability: Processes triggering extreme flood events are subjected to natural variability. The parameters representing these processes vary over time and space (Haimes, 1998). Plate (1992) stated that this variability is inherent to all natural processes. Regardless of how high the monitoring effort might be, it will never be possible to fully predict and describe these processes by means of a deterministic model. Uncertainty related to variability is traditionally covered by probabilistic methods (Apel et al., 2006; Apel et al., 2008; Merz, 2006).

- Limited information: Frequently there are statistical dependencies between variables used for risk analyses. In many cases data availability is not sufficient to describe these dependencies, which leads to an additional source of uncertainty in the frame of risk analyses (Merz, 2006). 


\section{- Parametric uncertainty}

- Measurement inaccuracy leads to random variation in measurements. To detect these random errors statistic methods (standard deviation, confidence interval etc.) are applied (Rabinovich, 1993).

- However, systematic errors can occur due to e.g. inaccurate calibration and experiment design. Systematic errors are rarely known since the true value is not determinable (Rabinovich, 1993, Ferson and Ginzenburg, 1996).

- Parameter uncertainty can result from simplified descriptions - approximations - of data and parameters, e.g. by representing a continuous random variable with a discrete one.

As a supplement to variables there are indicators and parameters representing ideals and moral concepts (e.g. value of human life expressed in salvage expenses or risk aversion factors) which influence the risk analysis (Haimes, 1998). These parameters represent a significant source of uncertainty in the frame of risk analysis.

\subsection{Study area}

The presented survey was carried out in the Ill river basin with a catchment area of $1300 \mathrm{~km}^{2}$, situated in the Western Austrian Alps (Fig. 1). The River Ill, with a mean annual discharge of $66 \mathrm{~m}^{3} / \mathrm{s}$, is the main river catchment in south-eastern Vorarlberg, the most-western federal state of Austria. Hydro-meteorological observations of precipitation, air temperature and runoff were gathered. Elevations range from 400 to $3000 \mathrm{~m}$ a.s.l. and the mean annual precipitation averages $1700 \mathrm{~mm}$. A 100 -year flood event is estimated at $820 \mathrm{~m}^{3} / \mathrm{s}$. Current, as well as historical surveying data (since 1978), were provided for $60 \mathrm{~km}$ of the River Ill and, altogether, $15 \mathrm{~km}$ of 8 tributaries comprising cross section measurements (with distances of $100 \mathrm{~m}$ on average) and airborne laser scan data. Sediment samples were drawn in 71 locations. Additional information on geographical features of the catchment (elevation, land cover, cadastral information and soil type) and on hydropower influence on the runoff regime was considered (Nachtnebel and Neuhold, 2008; Nachtnebel and Stanzel, 2008).

\section{Methodology}

The applied methodological approach was elaborated to analyse and quantify variability and uncertainty of single steps in the frame of hazard assessment and to enhance methodologies of vulnerability assessment. Therefore, the derivation of hydrological input, possible changes in river bed elevation due to sediment transport and the effects on

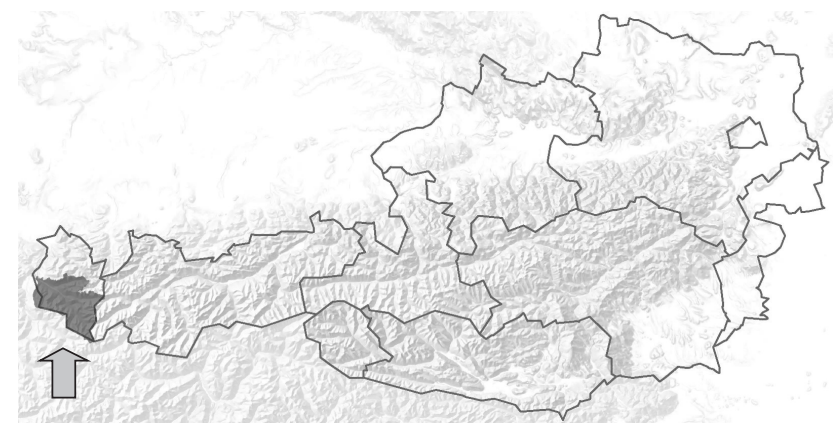

Fig. 1. Study area: Austria and the Ill river catchment in the west.

water surface elevations and subsequent potential dyke overtopping and inundation were dissected. Vulnerability analyses and damage estimation tools were methodologically improved by connecting the overtopping probability, the variability of inundation depths and object related damage functions to obtain a damage-probability relationship (Fig. 2).

Initially, the hydrology of the catchment was simulated with a semi-distributed precipitation-runoff model. Variability of the hydrograph was obtained by generating numerous scenarios with different initial moisture conditions and by considering different spatial and temporal distributions, durations and amounts of rainfall. The hydrologic model provided runoff scenarios which were subsequently used as an input for the hydraulic and sediment transport model. Additionally, the variability of possible morphological changes due to torrential sediment entry was analysed. For this purpose scenarios with randomly drawn sediment loads from torrential inflows based on probability distribution functions were developed to account for the uncertainty caused by sediment input to the system. The calculated morphological changes of the river bed provided a basis to estimate the variability of water surface levels and inundation lines which should be considered in flood hazard maps and flood risk maps. For each scenario the water table, river bed elevation and the respective inundation lines as well as inundation depths were obtained. Therefore, each exposed object can be linked to a distribution function consisting of estimated damages related to flood inundation height and inundation probability.

\subsection{Hydrology}

The continuous, semi-distributed rainfall-runoff model, COSERO, developed by the Institute of Water Management, Hydrology and Hydraulic Engineering, BOKU (Nachtnebel et al., 1993; Kling, 2002 among others) was applied to the Ill catchment. This model accounts for processes of snow accumulation and melt, interception, evapotranspiration, infiltration, soil storage, runoff generation and routing. Separation of runoff into fast surface runoff, inter flow and base flow is calculated by means of a cascade of linear and non-linear 


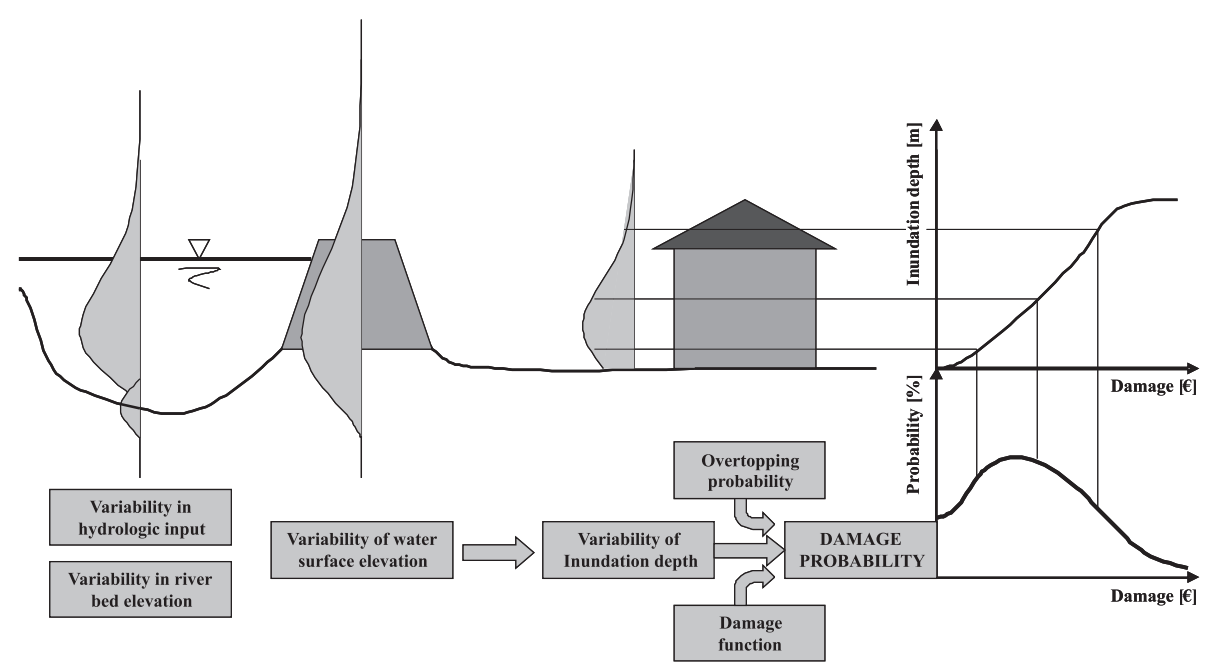

Fig. 2. Scheme of methodological approach to derive the damage probability of vulnerable utilisations.

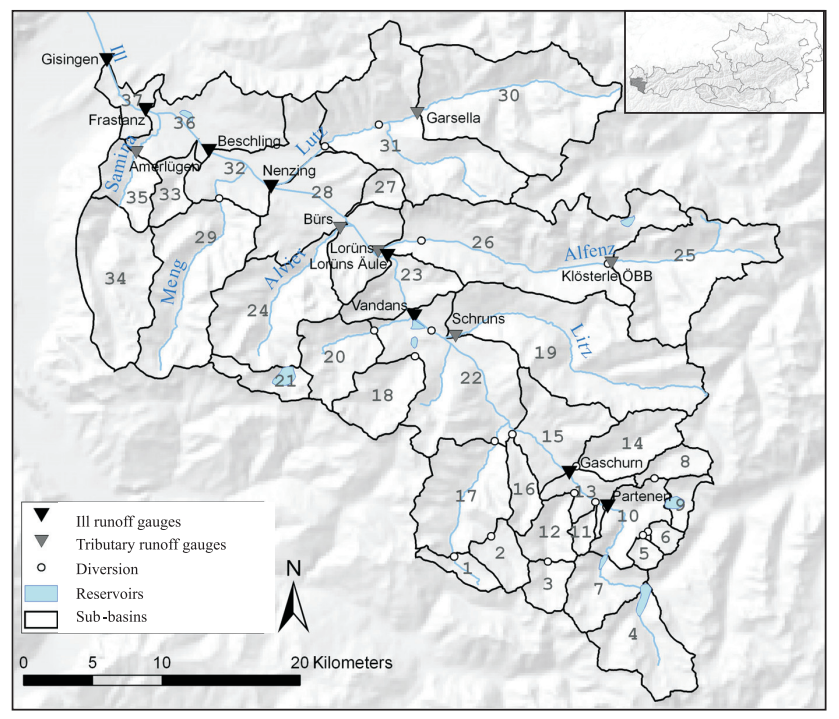

Fig. 3. Watershed of the River Ill and its sub-basins.

reservoirs. Spatial discretisation relies on the division of the watersheds into sub-basins and subsequently into hydrologic response units (HRUs).

The Ill watershed was divided into 37 sub-basins, based on the location of runoff gauges, anthropogenic diversions and reservoirs, with sub-basin areas ranging from 10 to $200 \mathrm{~km}^{2}$ (Fig. 3). $828 \mathrm{HRUs}$, with a mean area of $1.6 \mathrm{~km}^{2}$, were derived by intersection of $200 \mathrm{~m}$-elevation bands with soil type data (Peticzka and Kriz, 2005) and land use data (Fürst and Hafner, 2005).

The model was calibrated and validated based on observed discharge hydrographs of 6 years with continuous daily records and hourly records for 16 flood periods, measured at 14 gauges. Calibrated parameters of gauged sub-basins were transferred to neighbouring ungauged sub-basins. Stor- age coefficients for base flow and interflow, which correlated well with catchment size for the calibrated sub-basins, were assigned according to this relation. After this, storage coefficients for fast runoff were allocated in order to achieve characteristics of runoff separation into surface flow, interflow and base flow as simulated in neighbouring calibrated subbasins with similar physical features. Nash-Sutcliffe model efficiencies (Nash and Sutcliffe, 1970) between 0.80 and 0.90 for the calibration period and between 0.75 and 0.85 for the validation period were achieved. Mean relative peak errors of the 16 simulated flood periods ranged between $-15 \%$ and $+10 \%$.

After calibration, the rainfall-runoff model was applied to simulate flood runoff scenarios. Design storms with assumed return periods of 100 years were used as input. The underlying assumption of using design storms with a 100-year recurrence interval is that they may produce flood peaks of the same return period. While this premise can be regarded as appropriate for design purposes, it is clear that a rainstorm with a given return period may cause a flood with a higher or lower return period (Larson and Reich, 1972). This is mainly due to factors affecting the runoff peak like the distribution of rainfall in time and space or antecedent soil moisture. Therefore, several scenarios, with variations of major influencing factors, were defined. Precipitation scenarios were obtained by varying total precipitation depth, storm duration and temporal and spatial distributions. Each rainfall scenario was combined with three different initial catchment conditions, which were selected from simulated state variables of historical flood periods.

Storm duration of 12 and $24 \mathrm{~h}$ were selected for the assessment. Recorded events leading to floods in the years 2000, 2002 and 2005 showed rainfall duration within this range. These assumptions are also in accordance with the common procedure of testing storm duration up to twice the 
concentration time which is estimated as being 11 to $13 \mathrm{~h}$ for the Ill catchment (BMLFUW, 2006b). Precipitation depths of 100-year storms with $12 \mathrm{~h}$ duration were provided by a meteorological convective storm event model (Lorenz and Skoda, 2000). Design storms based on these meteorological modelling results are recommended by Austrian authorities (BMLFUW, 2006b) and therefore, are a common basis for design flood estimations in Austria. The values given by this model refer to point precipitation. Areal precipitation, to be used as input for rainfall-runoff modelling, is obtained by reducing the point precipitation values with areal reduction factors (ARF). The developers of the convective storm event model recommend two different procedures to determine such factors, both depending on catchment area, precipitation depth and duration of the storm (Lorenz and Skoda, 2000; Skoda et al., 2005). ARF resulting from these two calculations varied considerably and defined the range of ARF values used to reduce mean 12-hour point precipitation depths for the Ill catchment. As the analysis of longer events was also intended, precipitation depths of 24-h storms were based on statistical extreme value analyses provided by local Austrian authorities and values from the Hydrological Atlas of Switzerland (Geiger et al., 2004).

Total precipitation depth was disaggregated to 15 -min time steps applying three different temporal distributions, with peaks at the beginning, in the middle or at the end of the event. Three different spatial distributions were considered: a uniform distribution, a distribution with higher precipitation in the south and another with higher precipitation in the north of the watershed. The spatial patterns of the two nonuniform distributions correspond with typical distributions of precipitation in the catchment.

The described variations in the parameters: storm duration, areal reduction factors as well as associated precipitation depths and temporal plus spatial distributions of rainfall, generated 42 precipitation scenarios. The combination with three different initial catchment conditions led to 126 runoff scenarios (Fig. 4).

\subsection{Hydrodynamics and sediment transport}

The software package GSTAR-1-D Version 1.1.4, developed by the US Department of the Interior (Huang and Greimann, 2007), which includes 16 different sediment transport algorithms was applied. GSTAR-1-D (Generalized Sediment Transport for Alluvial Rivers - One Dimension) is a onedimensional hydraulic and sediment transport model for use in natural rivers and man-made canals. It is a mobile boundary model with the ability to simulate steady or unsteady flows, internal boundary conditions, looped river networks, cohesive and non-cohesive sediment transport, and lateral inflows. The model uses cross section data and simulates changes of the river bed due to sediment transport. It estimates sediment concentrations throughout a waterway given the sediment inflows, bed material, hydrology and hydraulics

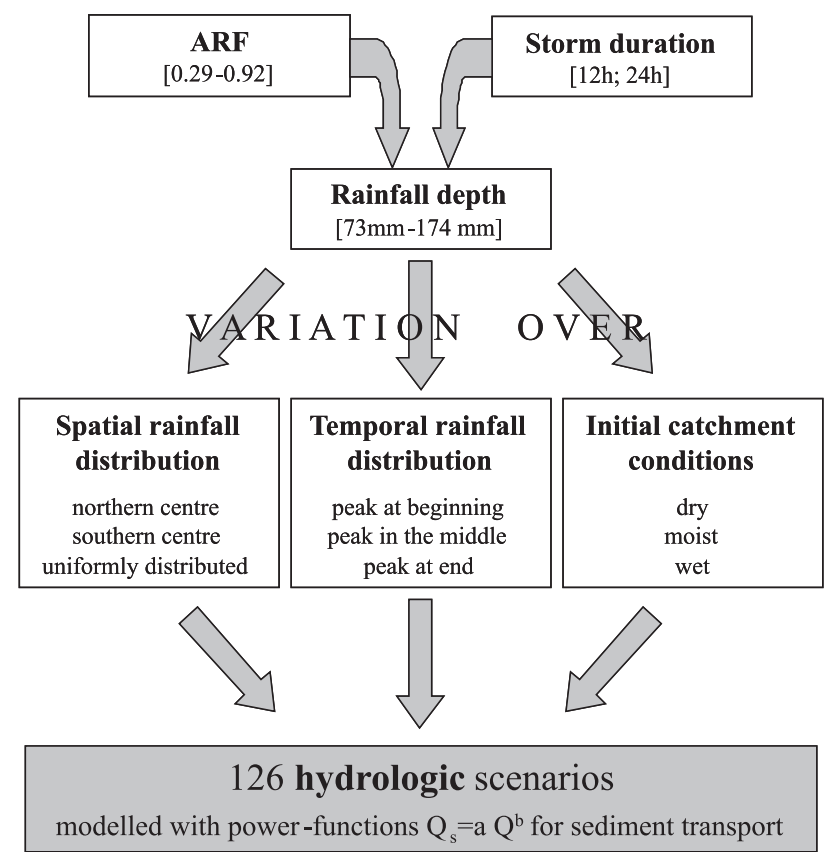

Fig. 4. Derivation of scenarios for hydrologic input variation.

of that waterway. Resulting from the one-dimension solutions for flow simulation the limitations are the neglection of cross flow, transverse movement, transverse variation and lateral diffusion. Therefore, the model cannot simulate such phenomena as river meandering, point-bar formation and pool-riffle formation. Additionally, local deposition and erosion caused by water diversions, bridges and other in-stream structures cannot be simulated (Huang and Greimann, 2007).

The model was calibrated and validated with runoff data from seven gauging stations by varying calculated roughness coefficients based on sediment samples. The sediment transport was calibrated and validated on historical cross section measurements (1978-2006) and the respective runoff time series as well as by balancing the calculated volumes of transported sediments. Hydrological input to the model was delivered by the precipitation-runoff model (Sect. 2.1). Boundary conditions as well as initial conditions concerning sediment transport were defined and derived from 71 drawn sediment samples.

A focus point of the study was to analyse and quantify modifications of river morphology and potential sediment inputs from torrential tributaries for extreme runoff scenarios $\left(\mathrm{HQ}_{1}, \mathrm{HQ}_{5}, \mathrm{HQ}_{30}\right.$ and $\left.\mathrm{HQ}_{100}\right)$. Considerable uncertainty rested upon the estimation of the input from torrential inflows. Therefore, the observed flood event from 2005, with an estimated recurrence interval of 100 years, was investigated in more detail. This approach accounts for the uncertainty of design-flood-event-based approaches, like state-ofthe-art methodologies for flood hazard mapping, whenever influences of morphological changes are neglected. 


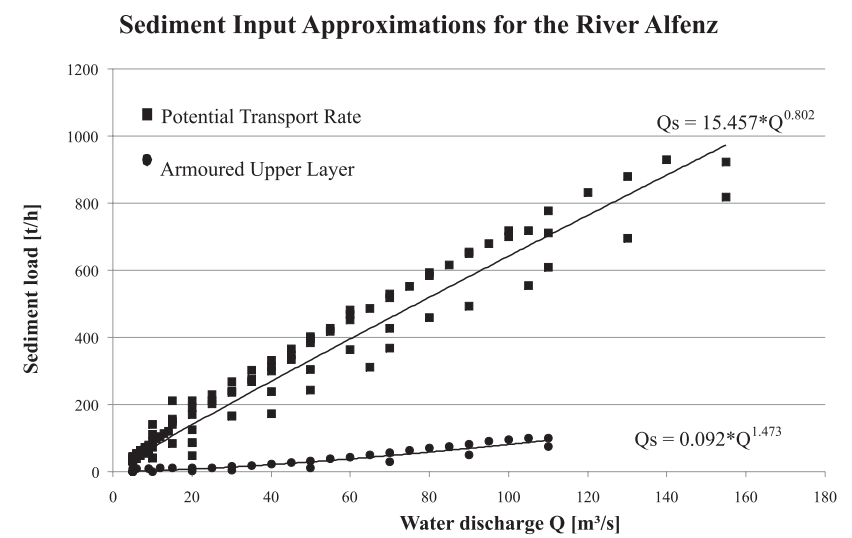

Fig. 5. Upper and lower sediment input boundary condition for the River Alfenz.

Sediment transport models were compiled for the main river system and eight tributaries. Two river bed conditions were defined for each tributary. The first of these assumed a fully-armoured upper layer with a mean layer thickness of $15 \mathrm{~cm}$ and the second model scenario calculated a river bed without any armouring. Therefore, this second state estimated the river's potential of sediment transport. Hence, two restricting transport functions were defined for each observed, measured and simulated tributary river (eight torrential inflows, see example for the River Alfenz in Fig. 5).

Input functions for 47 unobserved torrents were estimated on the basis of simulation results of observed tributaries. Sediment routing was solved with the Meyer-Peter and Müller formula (1948, Eq. 1), which is appropriate for alpine gravel-bed rivers:

$q_{b}^{2 / 3}\left(\frac{\gamma}{g}\right)^{1 / 3} \frac{0.25}{\left(\gamma_{s}-\gamma\right) d}=\frac{\left(K_{s} / K_{r}\right)^{2 / 3} \gamma R S}{\left(\gamma_{s}-\gamma\right) d}-0.047$

Where $\gamma$ and $\gamma_{s}=$ specific weights of water and sediment, respectively, $R=$ hydraulic radius, $S=$ energy slope, $d=$ mean particle diameter, $\rho=$ specific mass of water, $q_{b}=$ bed load rate in under water weight per unit time and width, $K_{s}=$ conveyance, $K_{r}=$ roughness coefficient and $\left(K_{S} / K_{r}\right) S=$ the adjusted energy slope that is responsible for bed-load motion.

In addition to 126 scenarios related to varying input hydrographs (Fig. 4), 12 scenarios were generated to elaborate the influence of randomly chosen sediment input events on bed elevation behaviour during high floods. Therefore, a minimum (armoured upper layer for all tributaries) and a maximum (no armouring for all tributaries) scenario, related to the restricting transport functions (e.g. Fig. 5), were defined. Within these extremes, 10 scenarios were compiled by randomly drawing input capacities of each torrential inflow dependent on the magnitude of the associated flood peak in the torrential sub-catchment. Thereby, maximum input represents an extreme event in the tributary itself and minimum input accounts for lower rainfalls in the sub-catchment.

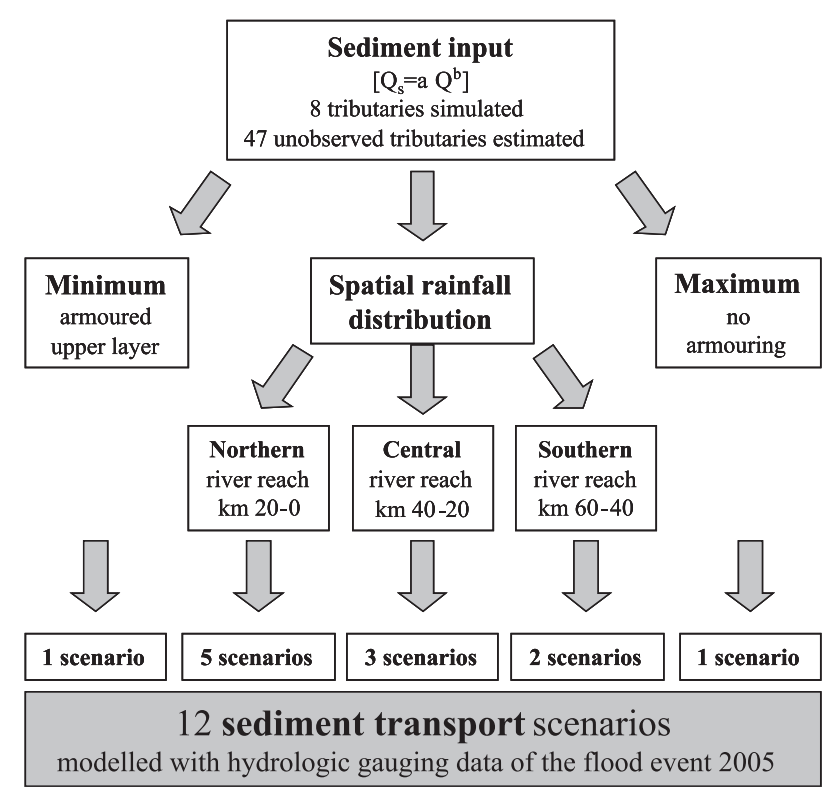

Fig. 6. Derivation of scenarios for sediment input variation.

The catchment area was divided into three sections of varying sediment input intensity (river kilometres 60-40, 4020 and 20-0) to obtain realistic input distributions. In the frame of the 10 scenarios only one of the three sections was allowed to be dominant by means of sediment input. Furthermore, a boundary condition for the acceptance of a randomly chosen scenario was defined: a minimum percentage of $50 \%$ related to the section's torrential catchment areas had to deliver maximum sediment input to account for rainfall clusters. The 12 resulting scenarios were simulated with observed and revised runoff data taken from the 2005 flood event with an estimated recurrence interval of 100 years (Fig. 6).

\subsection{Risk assessment}

The methodological enhancement was based on the risk assessment approach by BUWAL (1999a, b) which is characterised by a three-stage procedure. Each stage represents a self-contained step for risk analysis. Stages 1, 2 and 3 are arranged in increasing order of analytical detail. Risk can be analysed in one or more of the stages depending on the desired accuracy. In stage 1 , the hazard map is overlaid with a land use map to identify potential objects at risk.

In stage 2, the risks for spatial elements are quantified. Risks can, however, be analysed directly in stage 2 which is based on standardized damage values obtained by analyzing various ex-ante as well as ex-post damage estimations and documentations (Buck, 1999; BMFLUW, 2004; BUWAL, 1999a, b; BWG, 2002; Eberstaller, 2004; Faber, 2006; Nachtnebel and Faber, 2007; HYDROTEC, 2004; Kraus, 2004; Merz et al., 2004; Merz, 2006; Nachtnebel 
Table 1. Sensitivity of flood peaks due to input variation for Gisingen (basin outlet).

\begin{tabular}{lc}
\hline Varied Parameter & $\begin{array}{c}\text { Mean variation of simulated } \\
\text { runoff peaks at Gisingen }\end{array}$ \\
\hline Spatial rainfall distribution & $4 \%$ \\
Temporal rainfall distribution & $11 \%$ \\
Initial catchment conditions & $27 \%$ \\
Areal reduction factor & $88 \%$ \\
\hline
\end{tabular}

et al., 2005; Nachtnebel, 2007; Neuhold and Nachtnebel, 2008a, b; Niekamp, 2001; Rodriguez, 2001; Schanze et al., 2008; Schmidke, 2000; Statistik Austria, 2005a, b).

In stage 3 , risks are analysed on a micro scale level by specific investigations of individual objects (e.g. a building or section of a transport route at risk) (BUWAL, 1999a, b) and linking them to damage functions (inundation depth related to damage estimates).

Based on the micro scale level of stage 3 and, additionally, accounting for the variability of single processes (hydrology, hydrodynamics and sediment transport), derivations of probability distribution functions for object related inundation depths can be obtained. Whereas, the variability of the water surface elevation $\left(V_{W S E}\right)$ is dependent on the variability of the bed elevation $\left(V_{B E}\right)$, as well as on the variability of the hydrologic input $\left(V_{H I}\right)$.

$V_{W S E}=f\left(V_{B E} \mid V_{H I}\right)$

Relating the resulting variability of the water surface elevation (Eq. 2) with the dyke top edge elevation $(h)$, the variability of inundation depth $\left(V_{I D}\right)$ can be obtained on a micro scale basis (Eq. 3).

$V_{I D}=f\left(V_{W S E} \mid h\right)$

Corresponding to utilisation related damage functions $\left(f_{D}\right)$, typically based on the inundation depth $\left(h_{I}\right)$ and the associated damage $(D)$, a damage probability function $\left(f_{D P}\right)$ can be derived by multiplying the damage function (inundation depth dependent) with the variability of the inundation depth (Fig. 2, Eq. 4).

$$
f_{D P}=V_{I D} * f_{D}\left(D \mid h_{I}\right)
$$

\section{Results}

The following Sect. 3 describes the variability and uncertainty related to the processes hydrology, hydrodynamics and sediment transport as well as risk assessment based on the scenario analyses. The results of hazard assessment are expressed quantitatively, the results of vulnerability assessment qualitatively.

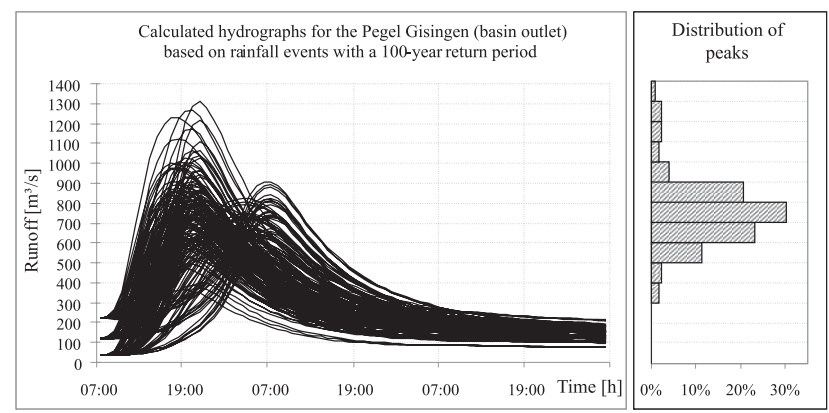

Fig. 7. Calculated hydrographs for 100-year rainfall events and distribution of simulated peak values.

\subsection{Hydrology}

Figure 7 illustrates 126 resulting 100-year flood waves as described in Sect. 2.1 and Fig. 4 for the catchment outlet at Gisingen as well as the relative distribution of the associated peak discharges. The effects of the applied parameter variations, which can be seen as a way of taking into account various uncertainties related to the hydrological assessment of design floods, are shown in Table. 1. Each variation of a single parameter over the full range of applied values - while keeping the others constant - yielded a maximum variation in resulting runoff peaks. For a relative measure this value was related to the mean of runoff peaks. The values given in Table 1 are the mean of relative peak variations for all considered scenarios. This mean relative variation shows the sensitivity of the flood simulation to changes in the respective parameter and establishes an evaluation approach for the respective uncertainty.

Regarding the basin outlet at Gisingen, the spatial distribution of rainfall had the smallest impact on flood peaks, because it is averaged over the catchment area. Obviously, this impact was much higher at the most-upstream gauges with a smaller catchment area (with either high or low precipitation), with relative runoff peak variations of up to $117 \%$. The mean variation for all Ill gauges was $41 \%$. Even though only three different spatial patterns were tested in this study, this shows that the importance of considering uncertainty of spatial rainfall distribution for design flood simulations depends on the spatial focus of the subsequent assessment. Other parameter variations lead to similar runoff peak variations at the basin outlet and at upstream gauges. The variation of ARF for 12-h storms had by far the largest effect on simulated flood hydrographs, as it directly altered the total depth of a precipitation scenario. Storm duration, the second parameter influencing total precipitation depth could not directly be assessed for the River Ill, because 12-h and 24-h storms were determined with different methods and other factors apart from duration influenced the resulting total depth. An evaluation of 2 to 12-h storms resulting only from the described meteorological convective storm model for Ill tributary sub-catchments showed mean variations in simulated 


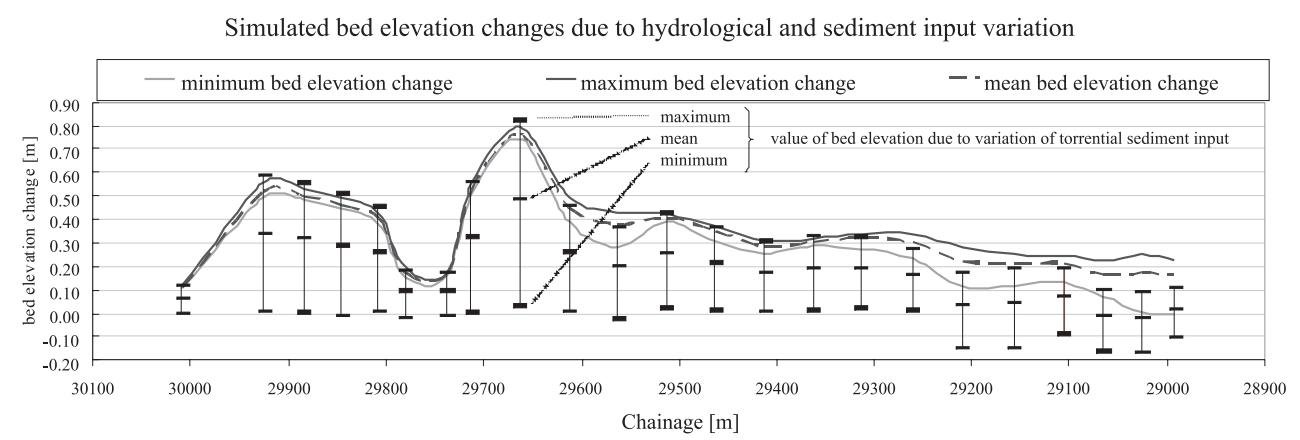

Fig. 8. Changes of river bed elevations due to hydrological and sediment input variation.

runoff peaks of 20\% (Stanzel et al., 2007). In this analysis also uncertainty related to the estimation of fast runoff model parameters was investigated. Resulting runoff peak variations in tributary rivers were rather small $(5 \%)$ - as better observations were available for calibration on the River Ill, the effects of uncertainty in parameter estimation is assumed to be even smaller when regarding the entire basin.

In relation to the normative 100-year design value of $820 \mathrm{~m}^{3} / \mathrm{s}$ at the gauge Gisingen, the simulated peaks ranged from $45 \%$ to $160 \%$. Several peaks were far below as well as over the $90 \%$ confidence interval of statistical extreme value analyses of observed runoff, underlining that 100 -year rainfall events produce flood events of different return periods. Yet, the large range of hydrographs shows how much of the possible variability of flood waves is disregarded by a design flood approach.

\subsection{Hydrodynamics and sediment transport}

Hydrodynamic and sediment transport simulation results are, as an example, illustrated for a highly dynamic section $(\mathrm{km}$ 30 to 29) chosen from the considered $60 \mathrm{~km}$. The selected river section is characterised by a torrential inflow located at the upper boundary. The sediment input function of this torrential inflow is documented in Sect. 2.2 and Fig. 5. The first $300 \mathrm{~m}$ of the considered reach are dominated by hydraulic structures (in- and outflow for energy generation, weir and chute) which cause spacious accumulations of sediment due to a reduction of flow velocity and accordingly to lower shear stress (Nachtnebel and Neuhold, 2008). In the case of higher discharge the accumulated sediment moves downstream where a dynamic river bed is encountered.

In Fig. 8 the modifications of river bed elevations due to hydrological and sediment input variations are illustrated. The three lines represent the maximum (dark grey), the mean (dashed grey) and the minimum (light grey) calculated bed elevation changes resulting from varying the discharge (Fig. 7) by means of 126 scenarios (Fig. 4). The inflow of the tributary just before $\mathrm{km} 30$ leads to locally calculated accumulations of almost $0.80 \mathrm{~m}$. The black vertical lines indicate the station of the considered cross sections and display the range of calculated bed elevation changes due to randomly selected sediment input of torrential inflows. The magnitude is based on the simulation of 12 input scenarios (Fig. 6) with a minimum input due to assumed armoured bed layers and a maximum sediment input represented by the restricting transport functions (Fig. 5).

Figure 9 outlines the maximum and minimum differences between water surface elevation and embankment elevation. The continuous lines correspond to the orographic right-hand hinterland where numerous utilisations such as private housing are situated. The thicker lines define the limits due to hydrological input variation and the thinner ones, the limits due to sediment input scenarios. Corresponding to the orographic left-hand side, where no utilisations worthy of protection were recorded, results are represented by grey dashed lines (thick for hydrology and thin for sediment input). The value 0.00 represents a water surface elevation equal to the dyke top edge. Overtopping occurs when displayed lines show positive values.

Due to hydrologic input variation (126 scenarios - 25\% of them exceed the design water level, see Fig. 7), a high probability of overtopping is indicated. Considering sediment input variation (12 scenarios) based on discharge data of a 100-year flood (2005) only the lower part of the section is subjected to inundation. From chainage $29100 \mathrm{~m}$ to $29000 \mathrm{~m}$ even the minimum values of calculated water surface elevations lead to inundation of the flood plain. Therefore, damages have to be expected prior to the design value of the protection scheme (recurrence interval of 100 years, including freeboard).

\subsection{Risk assessment}

The associated uncertainty of results obtained by designflood-based procedures (BMFLUW, 2006a) is emphasized by the overtopping probability caused by 138 considered scenarios (Fig. 10). Alongside the River Ill settlements and utilisations are mainly protected by dykes and natural barriers with an estimated flood safety up to a recurrence interval of 100 years. Figure 10 outlines the probability of over- 


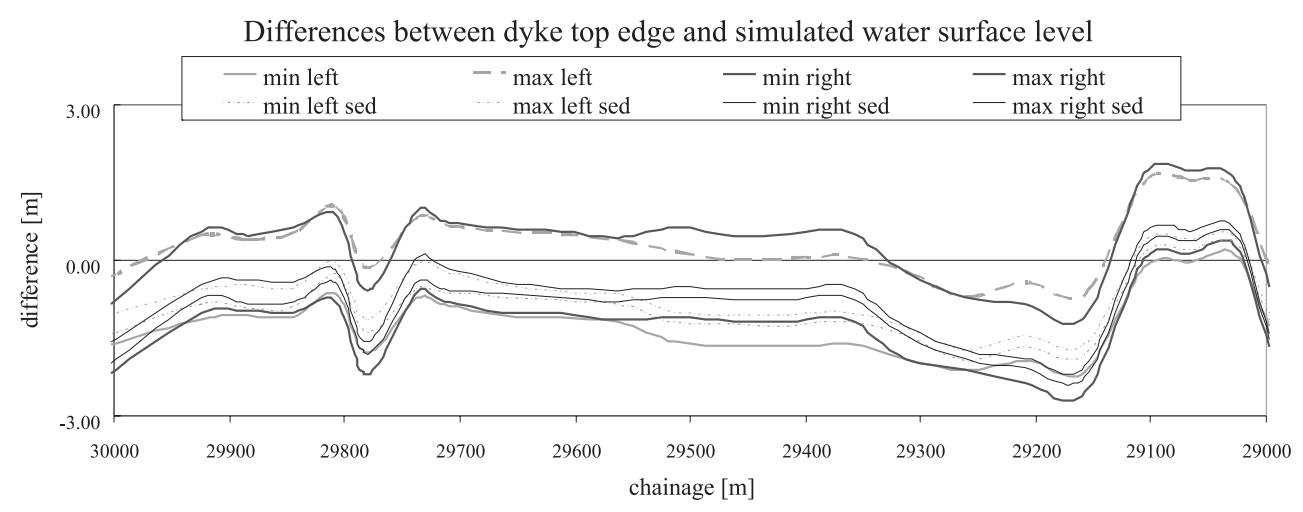

Fig. 9. Differences of water surface elevations and dyke top edge.

topping along the $60 \mathrm{~km}$ due to variation of discharge input (126 scenarios).

The calculated overtopping probability of $12.27 \%$ indicates that $7.4 \mathrm{~km}$ are not protected against floods caused by 100-year rainfall events which had not been previously identified as such. In the frame of this study affected utilizations were not elaborated in detail. The analysis of the section displayed in Fig. $9(\mathrm{~km} \mathrm{30-29)}$ proves that there are also settlements in the inundated areas. Referring to the results of the hydrological input variation, it has to be distinguished, that considered discharges resulting from 100-year rainfall events lead to as much as $160 \%$ of the applied design value discharge (normative 100-year flood event) for the gauge furthest downstream. Analysing scenarios by means of sediment input variation obtained by an observed 100-year flood event in the year 2005 the overtopping probability equals $1.59 \%$ for the entire reach. Nevertheless, at 40 cross sections dykes or barriers are overtopped and therefore most likely to break.

\section{Conclusions}

The key issues of the survey were to integrate river morphological changes during floods into risk estimation tools and to assess the associated uncertainties. Hydrological, hydrodynamic, sediment transport and risk assessment aspects were considered and analysed. Obviously, uncertainty increases by including additional processes such as sudden changes of the river bed. However, the opportunity to identify related uncertainty is provided. Hence, flood risk management strategies can be reviewed with regard to implementing the EU Flood Directive to national legislation.

In the frame of this survey risk assessment was adapted by substituting the scenario approach (a few normatively defined design floods) through a multi scenario approach by means of variation of input hydrographs and sediment load. Due to the incorporation of the impacts of hydrological and morphological processes on water surface tables, a refined hazard assessment approach is provided which was quantita-

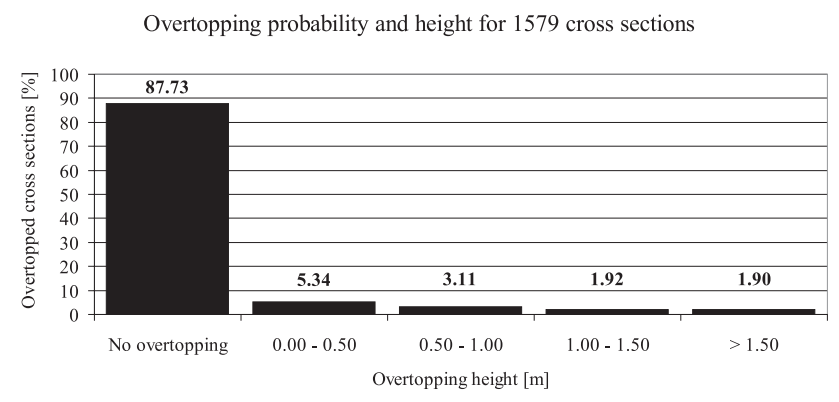

Fig. 10. Overtopping probability and height.

tively applied to the presented case study. Vulnerability analyses and damage estimation tools were improved methodologically by interrelating the overtopping probability, the variability of inundation depth and a damage function to obtain a damage-probability relationship. Therefore, uncertainty and sensitivity are implicitly comprised in the probability distribution function of the expected damage.

Discharge input scenarios were obtained by rainfall-runoff simulations with different 100-year rainfall events. Sediment input scenarios were simulated based on a flood event with an estimated recurrence interval of 100 years by randomly drawing loads of torrential inflows. A sensitivity analysis indicated that the discharge input variation leads to flood peaks as high as $160 \%$ of the normative 100-year design flood. Hence, a higher probability of inundations of vulnerable utilizations like settlements, infrastructure, etc. resulted from discharge input variation $(12.3 \%)$ than from sediment input variations $(1.6 \%)$. Therefore, the hazard assessment outlines that damage has to be assumed where safety was expected.

Regarding the magnitude of bed elevation changes, however, the influence of sediment input variation was found to be much higher than the influence of discharge input variations. Consequently, the derivation of sediment input functions appears to be the most important task wherever the incorporation of sediment transport calculations or estimations are applicable. In this context scarce data availability 
seems to be the restricting factor (Nachtnebel and Neuhold, 2008). Therefore, an enhancement of continuous sediment gauges as well as the volumetric survey of accumulations, especially after flood events, is desirable. By means of an extended data base the derivation of sediment input functions as well as calibration and validation of sediment transport models would be more feasible and should be adaptable to further river types and scales.

Edited by: J. Birkmannm

Reviewed by: two anonymous referees

\section{References}

Apel, H., Merz, B., and Thieken, A. H.: Influence of Dike Breaches on Flood Frequency Estimation, Computers and Geosciences, 35/5, 907-923, 2009

Apel, H., Thieken, A. H., Merz, B., and Blöschl, G.: A probabilistic Modelling System for Assessing Flood Risks, Natural Hazards, 38(1-2), 79-100, 2006.

BMFLUW (Bundesministerium für Forst- und Landwirtschaft, Umwelt und Wasserwirtschaft): Analyse der Hochwasserereignisse vom August 2002 - Flood RISK, WP Donau TP 05, Operative Maßnahmen Donau, 2004.

BMFLUW: Richtlinien zur Gefahrenzonenausweisung für die Bundeswasserbauverwaltung, Fassung 2006, Wien, BMFLUW, 2006a.

BMLFUW: Niederschlag-Abfluss-Modellierung; Arbeitsbehelf zur Parameterermittlung (in German), Federal Ministry of Agriculture, Forestry, Environment and Water Management, Vienna, $2006 b$.

Buck, W.: Auswertung der HOWAS-Datenbank: HY 98/15, Karlsruhe, Institut für Wasserwirtschaft und Kulturtechnik, Universität Karlsruhe, 1999.

BUWAL: Risikoanalyse bei gravitativen Naturgefahren - Methode, Umwelt-Materialien Nr. 107/I, Naturgefahren: Bern, Bundesamt für Umwelt, Wald und Landschaft, 1999a.

BUWAL: Risikoanalyse bei gravitativen Naturgefahren - Fallbeispiele und Daten, Umwelt-Materialien Nr. 107/II, Naturgefahren: Bern, Bundesamt für Umwelt, Wald und Landschaft, 1999b.

BWG: Methode BWG Abschätzung des Schadenspotentials bei Überschwemmung und Übermurung, Arbeitshilfe 1.2, 2002.

Eberstaller, J.: Raumordnung und Hochwasserschutz am Beispiel der Traisen - Siedlungsentwicklung und Schadensanalyse, TP 02 - Naturgefahren BWV, in: Analyse der Hochwasserereignisse vom August 2002 - Flood Risk. Hrsg: BMLFUW, 2004.

Faber, R.: Flood Risk Analysis: Residual Risks and uncertainties in an Austrian context, Dissertation, University of Natural Resources and Applied Life Sciences, 143 pp., 2006.

Ferson, S. and Ginzenburg, L. R.: Different methods are needed to propagate ignorance and variability, Reliability Engineering and System Safety, 54, 133-144, 1996.

Fürst, J. and Hafner, N.: Land cover, in: Federal Ministry of Agriculture, Forestry, Environment and Water Management, Hydrological Atlas of Austria, 2nd Edition, Vienna, 2005.

Geiger, H., Röthlisberger, G., Stehli, A., and Zeller, J.: Extreme point rainfall of varying duration and return period, in: Swiss
National Hydrological and Geological Survey 2004, Hydrological Atlas of Switzerland, Bern, 2004.

Haimes, Y. Y.: Risk modeling, assessment and management, Wiley Series in Systems Engineering, John Wiley and Sons, Inc., 726 pp., 1998.

Hall, J. and Solomatine, D.: A framework for uncertainty analysis in flood risk management decisions, International Journal of River Basin Management, 6, 85-98, 2008.

Huang, J. V. and Greimann, B.: US Department of Interior, Bureau of Reclamation, Technical Service Center, Sedimentation and River Hydraulics Group, User's Manual for GSTAR-1 D, 181, 2007.

HYDROTEC: Hochwasser-Aktionsplan Sieg- Gemeinschaftsprojekt der Länder Nordrhein-Westfalen und Rheinland-Pfalz, Ministerium für Umwelt und Naturschutz, Landwirtschaft und Verbraucherschutz, http://www.stua-si.nrw.de/sieg/bericht/01.html, 2004.

Kaplan, S. and Garrick, B. J.: On the quantitative definition of risk, Risk Analysis, 1(1), 11-27, 1991.

Kling, H.: Development of tools for a semi-distributed runoff model, Master thesis, Institute of Water Management, Hydrology and Hydraulic Engineering, University of Natural Resources and Applied Life Sciences, Vienna, Austria, 2002.

Kraus, D.: Wirtschaftlichkeit und Priorisierung von Schutzmaßnahmen vor Wildbächen, Erosion und Lawinen: IAN Report 94: Workpackage (WP) Naturgefahren Wildbach- und Lawinenverbauung (WLV) Teilprojekt (TP) 03 in BMFLUW, 2004.

Kuikka, S. and Varis, O.: Uncertainties of climate change impacts in Finnish watersheds: a Bayesian network analysis of expert knowledge, Boreal Env. Res., 2, 109-128, 1997.

Larson, C. L. and Reich, B. M.: Relationship of observed rainfall and runoff recurrence intervals, in: Floods and Droughts, edited by: Schulz, E. F., Koelzer, V. A., and Mahmood, K., Water Resources Publications, Fort Collins, 34-43, 1972.

Lorenz, P. and Skoda, G.: Bemessungsniederschläge kurzer Dauerstufen ( $D \leq 12$ Stunden) mit inadäquaten Daten (in German), Report of the hydrographical service in Austria, Nr. 80, Vienna, 2000.

Merz, B., Kreibich, H., Thieken, A., and Schmidtke, R.: Estimation uncertainty of direct monetary flood damage to buildings, Nat. Hazards Earth Syst. Sci., 4, 153-163, 2004, http://www.nat-hazards-earth-syst-sci.net/4/153/2004/.

Merz, B.: Hochwasserrisiken - Grenzen und Möglichkeiten der Risikoabschätzung, E. Schweizerbart'sche Verlagsbuchhandlung (Näglele u. Obermiller), Stuttgart, 2006.

Messner, F., Penning-Rowsell, E., Green, C., Meyer, V., Tunsall, S., and van der Veen, A.: Evaluating flood damages: guidance and recommendations on principles and methods, report number T09-06-01, www.floodsite.net, 2007.

Meyer-Peter, E. and Müller, R.: "Formula for bed-load transport" Proc. of the Int. Assoc. for Hydraulic Research, 2nd Meeting, Stockholm, 1948.

Murphy, B. L.: Dealing with uncertainty in risk assessment, Human and Ecological Risk Assessment, 4, 685-699, 1998.

Nachtnebel, H. P., Baumung, S., and Lettl, W.: Abflussprognosemodell für das Einzugsgebiet der Enns und Steyr (in German), Report, Institute of Water Management, Hydology and Hydraulic Engineering, University of Natural Resources and Applied Life Sciences Vienna, Austria, 1993. 
Nachtnebel, H. P. and Debene, A.: Suspended sediment balance in runoff river reservoirs along the Austrian Danube. "Schwebstoffbilanzierung im Bereich von Stauräumen an der österr. Donau", FloodRisk: Endbericht im Auftrag des Lebensministeriums, in: Habersack H., Bürgel J., and Petraschek A.: Analyse der Hochwasserereignisse vom August 2002 - Flood Risk, 2004, BMLFUW, Wien, Österreich, 2004.

Nachtnebel, H. P., Faber, R., and Leroch K.: Risikoanalyse des bestehenden Hochwasserschutzes Stadt Gleisdorf und Umgebung, River Basin Agenda, Wien, IWHW, BOKU, 2005.

Nachtnebel H. P. and Faber, R.: Assessment and management of flood risks in Austria, Structure and infrastructure Engineering: Maintenance, Management, Life-Cycle Design and Performance, 5/4, 333-339, 2009.

Nachtnebel, H. P.: Cost-benefit evaluation of risk reduction options, Proceedings, European Symposium on Flood Risk Management Research (EFRM 2007), 6th-7th February 2007, Dresden, Germany, 2007.

Nachtnebel, H. P. and Neuhold, C.: Schutzwasserbauliche Bestandserhebung Ill - AP 5: Hydraulik/Geschiebe/Schwebstoffe, Amt der Vorarlberger Landesregierung, 164, 2008.

Nachtnebel, H. P. and Stanzel, P.: Schutzwasserbauliche Bestandserhebung Ill - AP 4: Hydrologi, Amt der Vorarlberger Landesregierung, $161 \mathrm{~S}, 2008$.

Nash, J. E. and Sutcliffe, J. V.: River Flow Forecasting through Conceptual Models, J. Hydrology, 10/3, 282-290, 1970.

Neuhold, C. and Nachtnebel, H. P.: Detailed residual risk assessment in an Austrian municipality, in: European Geosciences Union, Vol. 10, 2008, EGU General Assembly 2008, EGU General Assembly 2008, 14.04.2008-18.04.2008, Wien, 10; ISSN 1029-7006, 2008a.

Neuhold, C. and Nachtnebel, H. P.: Flood risk assessment in an Austrian municipality comprising the evaluation of effectiveness and efficiency of flood mitigation measures, FLOODrisk2008, Proceedings, London: Taylor and Francis, 2008b.

Niekamp, O.: Hochwasserschäden, in: Hochwasser-Handbuch, Auswirkungen und Schutz/Hrsg.: Heinz Patt. Springer, 2001.

Peticzka, P. and Kriz, K.: General soil map, in: Federal Ministry of Agriculture, Forestry, Environment and Water Management, Hydrological Atlas of Austria, 2nd Edition, Vienna, 2005.
Plate, E. J.: Stochastic design in hydraulics: concepts for a broader application, in: Kuo, J. T. and Lin, G. F., edited by: Stochastic Hydraulics '92, Proc. 6th IAHR International Symposium on Stochastic Hydraulics, Taipei, Taiwan, May, 18-20, 1992 , Dept. Civil Engineering, National Taiwan University, Taipei, Taiwan, 663-670, 1992.

Popper, K.: The open universe, Hutchinson, London, 185 pp., 1982.

Rabinovich, S.: Measurement errors: Theory and practice, American Institute of Physics, New York, 1993.

Rodriguez, R.: Hochwassergefahrenkarten für Deutschland Zusammenfassung und Vorschlag für ein koordiniertes Vorgehen der Bundesländer, Teil 1: Voraussetzungen für die Erstellung von Hochwassergefahrenkarten, in: Hochwassergefahrenkarten, 2005.

Skoda, G., Weilguni, V., and Haiden, T.: Heavy Convective Storms - Precipitation during 15, 60 und 180 minutes, in: Federal Ministry of Agriculture, Forestry, Environment and Water Management, edited: Hydrological Atlas of Austria, 2nd Edition, Vienna, 2005.

Schanze, J., Hutter, G., Harries, T., Holzmann, H., Koeniger, P., Kuhlicke, C., Meyer, V., Nachtnebel, H. P., Neuhold, C., Olfert, A., Parker, D., Penning-Rowsell, E., Schildt, A., and Werritty, A.: Systematisation, evaluation and context conditions of structural and non-structural measures for flood risk reduction ERANET CRUE funding initiative, 131, 2008.

Schmidke, R. F.: Klimaveränderung - sozioökonomische Konsequenzen, Karlsruhe: Landesanstalt für Umwelt, Messungen und Naturschutz Baden-Württemberg (LUBW), 269-276. http: //www.kliwa.de, 2000.

Stanzel, P., Neuhold, C., and Nachtnebel, H. P.: Estimation of design floods for ungauged basins in an alpine watershed, in: European Geosicences Union, Geophysical Research Abstracts, Vol. 9, 2007, EGU General Assembly, 15-20, April 2007, Vienna, 2007.

Statistik Austria: Ein Blick auf die Gemeinde - 61713-Gleisdorf Gemeindedaten, http://www.statistik.at/blickgem/gemDetail.do? gemnr=61713\&gemnam=Gleisdorf, 2005a.

Statistik Austria: Leistungs- und Strukturstatistik - Unternehmen und Arbeitsstätten, http://www.statistik.at/web_de/statistiken/ unternehmen_arbeitsstaetten/leistungs-_und_strukturdaten/index. html, 2005b. 